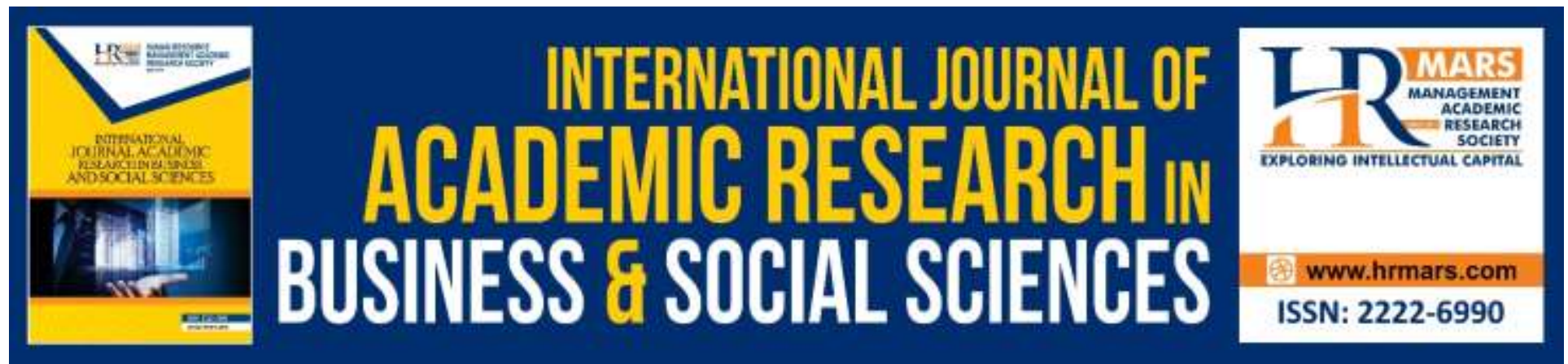

\title{
Technological Environment and Performanc of Deposit Money Banks in Enugu state, Nigeria
}

Ndubuisi-Okolo Purity. U and Nwatu Chukwemeka

To Link this Article: http://dx.doi.org/10.6007/IJARBSS/v10-i6/7282

DOI:10.6007/IJARBSS/v10-i6/7282

Received: 22 March 2020, Revised: 27 April 2020, Accepted: 25 May 2020

Published Online: 24 June 2020

In-Text Citation: (U \& Chukwemeka, 2020)

To Cite this Article: U, N.-O. P., \& Chukwemeka, N. (2020). Technological Environment and Performanc of Deposit Money Banks in Enugu state, Nigeria. International Journal of Academic Research in Business and Social Sciences, 10(6), 231-256.

Copyright: (C) 2020 The Author(s)

Published by Human Resource Management Academic Research Society (www.hrmars.com)

This article is published under the Creative Commons Attribution (CC BY 4.0) license. Anyone may reproduce, distribute, translate and create derivative works of this article (for both commercial and non-commercial purposes), subject to full attribution to the original publication and authors. The full terms of this license may be seen

at: http://creativecommons.org/licences/by/4.0/legalcode

Vol. 10, No. 6, 2020, Pg. 231 - 256

http://hrmars.com/index.php/pages/detail/IJARBSS

JOURNAL HOMEPAGE

Full Terms \& Conditions of access and use can be found at http://hrmars.com/index.php/pages/detail/publication-ethics 


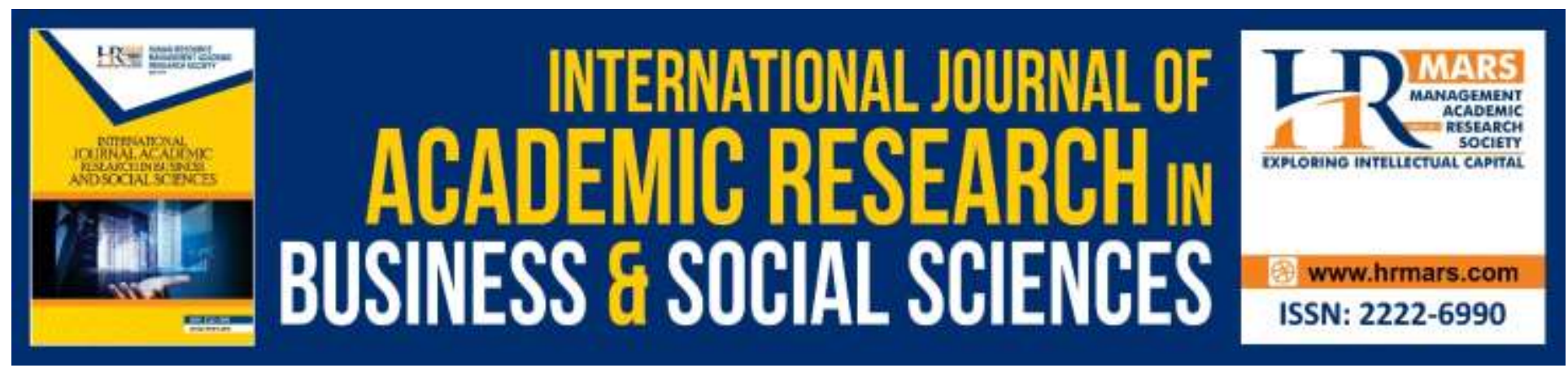

\title{
Technological Environment and Performanc of Deposit Money Banks in Enugu state, Nigeria
}

\author{
Ndubuisi-Okolo Purity. U (Ph.D) and Nwatu Chukwemeka \\ Department of Business Administration, Faculty of Management Sciences, Nnamdi Azikiwe \\ University, Awka, Anambra State. \\ Email: purend2@yahoo.com
}

\begin{abstract}
Technological changes all over the world and globalization have posed great challenges to the Nigeria Banking sector. The study focuses on technological environment and performance of Deposit Money Banks in Enugu State. The specific objectives were to determine the extent to which perceived usefulness of technology influence innovation/creativity in the Deposit Money Banks of Enugu State, ascertain the nature of the relationship between perceived ease of use and customer satisfaction in the Deposit Money Banks of Enugu State, and examine the effect of technological facilities on employee performance in Deposit Money Banks of Enugu State. The study had a population size of 344, out of which a sample size of 185 was realized using Taro Yamane's formula at 5\% error tolerance and 95\% level of confidence. An instrument used for data collection was primarily questionnaire. Out of 185 copies of the questionnaire that were distributed, 164 copies were returned while 21 were not returned. The survey research design was adopted for the study. The hypotheses were tested using Pearson Product Moment Correlation coefficient and Simple Linear Regression statistical tools. The findings indicated that Perceived usefulness of technology to a large extent influenced innovation/creativity in Deposit Money Banks of Enugu State $(r=0.897 ; F=668.948 ; t=3.448 ; p<0.05)$. There was a positive relationship between perceived ease of use and customer satisfaction in Deposit Money Banks of Enugu State $(r=.740, P<.05)$. Technological facilities significantly affected employee performance in Deposit Money Banks of Enugu State $(r=0.843 ; F=397.990 ; t=3.873 ; p<0.05)$. The study concluded that the technological environment effectively promotes banking activities and at the same time encourages customer satisfaction. The study recommended that financial institutions should create a platform where they will educate their customers on how to use the e- banking facilitates which will go a long way to boost customer satisfaction in most banks.
\end{abstract}

Keywords: Technological Change, Globalization, Employee Performance. 


\section{Background of the Study}

The phenomenon of global economy has influenced the rapid changes in technology development. Global economy brings new approaches to business thinking and creates a new economic paradigm with changes in corporate culture, in the corporate environment, especially in the requirements of suppliers and customers. These rapid changes do influence not only the economic system, industry and enterprises, but also the technological development if it is to fulfill economic needs. (Bedřich, Veronika, and Zdeněk, 2012).

In this modern world of rapid technological changes, technological advancement will continue to accelerate the future. Technological advancement change the organizational policies and strategies (Hampel and Martinsons, 2009).In any organization, most of challenges are generated by competition, advanced technology, enhancing employee efficiency and repaid growth, new leadership and management (Madsen, Miller, \& John, 2005)

Today's banking business is universal, extremely obsessed and technologically driven most especially with the advancement in information technology (Parnell, 2013). According to Parnell (2013) the resulting business tasks for strategist in organizations is vast, unstructured and woolly, and would demand effective and efficient strategies that could provide sustained competitive advantage and the achievement of superior performance.

A business environment comprises of such factors as infrastructure, cultural, economic, social, technological and political environments. These environmental forces have been found to be capable of either impeding or facilitating banking activities in any economy. However in today's competitive environment, the great majority of firms find that a flexible attitude is the only way to preserve their current position or gain a competitive advantage (Dugal and Roy, 1996; Gemunden, Heydebreck, and Herden, 1992; Grindley and Teece, 1997). Companies of all sizes and nearly all industries license the production of products and services, but there is evidence to believe that the incidence is higher in technically complex and research-active industries such as aircraft, communication, industrial machinery, computers, and chemicals. (Arora, 1997; Grindley and Teece, 1997).

Technological environment plays a vital role in enhancing the operational efficiency of the firm, improving the quality of products and reducing the operational cost by installing the latest and sophisticated technology. Advanced Manufacturing Technology helps the firm to gain competitive advantage (Pagell, Handfield, \& Barber, 2000). Advanced Manufacturing Technologies help the manufacturing firms to produce high volume at low cost and thus rationally utilize the scarce resources available at its disposal (Goldhar and Jelinek, 1983).

Technological environment perpetually helps to the improve the performance of manufacturing industries and it helps the enterprises to formulate the manufacturing strategy and gain competitive advantage, improve productivity, reduce operation time, and increase the flexibility and customers satisfaction (Boody and Buchanan,1986).

Moreover organizations purchase the advanced technological tools for improving the employee's performance, facilitating job-tasks, improving communication, increased efficiencies, and higherlevels of effectiveness in work management. The introduction of advance technology has 
changed the way of performing jobs. Technological advancement improved the employee performance as well as reduced the employee working effort and task completion time (Muhammad, Nadeem and Huzaifah, 2014).

Applying technology in the workplace allows banks to expand quickly and efficiently. Business technology such as video conferencing, social networks and virtual office technology has removed workplace boundaries that previously limited business expansion. With business technology, banks can target a wider customer base and grow to higher levels. The technological environment influences the decision to license innovations, particularly through its influence on input and output activities and the types of technology adopted by the banks (Bourgeois, 1985; Rousseau, 1979).

\section{Statement of the Problem}

Globalization of the economy and recent technological changes have transformed the business environment, with new challenges and opportunities emerging for banks. Increased competition, developing customer needs and responsiveness to firm's environment has become a vital factor for financial institutions. This is to say that a financial institution's product /services could be the result of complex activities. Most banks today work very hard to enhance their services/ products before offering them to customers. Value-adding could be in the form of increasing the products prices and value. However, any financial institution that fails to scan their technological environment in order to detect opportunities and threats are bound to experience low productivity, and profitability index, decline in customer satisfaction and may be overcome by fellow competitors thus the study investigated Technological Environment and Performance of money deposit banks in Enugu state, Nigeria.

\section{Objectives of the Study}

The main objective of this study was to determine the effect of technological environment on performance of money deposit banks in Enugu state.

The specific objectives are to:

i. Determine the extent to which perceived usefulness of technology influence innovation/creativity in Money Deposit Banks of Enugu state

ii. Ascertain the nature of relationship between perceived ease of use of technology and customer satisfaction in Money Deposit Banks of Enugu State

iii. Examine the effect of various technological facilities on performance in money deposit banks of Enugu State

\section{Research Questions}

With the above objectives in focus, the study found answers to the following questions

i. To what extent does perceived usefulness of technology influence innovation/creativity in Money Deposit Banks of Enugu State?

ii. What is the nature of relationship between perceived ease of use of technology and customer satisfaction in Money Deposit Banks of Enugu State?

iii. What is the effect of various technological facilities on performance in Money Deposit Banks of Enugu State 


\section{Research Hypotheses}

These hypotheses were proposed for the study

i. Perceived usefulness of technology to a large extent influences innovation/creativity in Money Deposit Banks of Enugu State

ii. There is a positive relationship between perceived ease of use of technology and customer satisfaction in Money Deposit Banks of Enugu State

iii. Technological facilities significantly affect performance in Money Deposit Banks of Enugu State

\section{Scope of the Study}

The study focuses on technological environment and performance of Money Deposit Banks in Enugu State, Nigeria. Geographically the regional headquarters of the banks are located at Enugu Urban and they are: First bank, Union bank, Diamond bank, Zenith bank and GTB plc. The contextual variables are Perceived usefulness of technology, perceived easy to use, Technological facilities, employee performance, customer satisfaction, and productivity. The study covers the time period between 2010-2017.

\section{Limitations of the Study}

As part of the research experience by researchers all over the world certain limitations hinder effective collection of materials.

1. Scarcity of materials: There is generally non-availability and adequate literature on the research topic. Hence the researcher finds it cumbersome to finalize the researcher paid for the classified material that was how he overcomes the limitation.

2. Non-challant attitude of respondents: Another limitation in the course of carrying this study was the non- challant attitude of the respondents in supplying the necessary information. This was probably due to their ignorance of the main purpose of the study. the researcher over this limitation by given the respondents gift for fill the questionnaire and grant oral interview.

3. Also many refused to grant interviews or answer questions bordering on the activities of their bank. The researcher used gifts to induce the respondents to answer his questions and fill the questionnaire

\section{Operational Definition of Terms}

The following terms that have several other meanings are defined below in the context of their usage in this study.

Environment:- All elements outside the organization's control that are relevant to its operations and survival.

Organization:- An entity where legal activities are carried on by two or more individuals to attain certain objectives under supervision.

Management: Sets of people who oversee the activities of the organization to ensure that the set objectives are achieved. 
Business Organization: Organization that is primarily oriented towards making profit. Organizational Structure: This is the frame work through which an organization allocates responsibilities for accomplishment of Organizational Objectives.

Organizational Capability: Inherent Capacity or Potential of an Organization.

Technological Environment: This represent a major opportunities and threats to the operations of business organizations, as well as measures the relationship that exits between production technology and structure of the organization with the organizational performance.

Performance: Something accomplished, efficient implementation/delivery of a services or an act.

\section{Review of Related Literature Conceptual Framework}

Onwuchekwa (2000) defined the environment of a business organization as those individuals, organizations, governmental /regulatory agencies, institutions, credit entities with whom an organization interacts to produce its products and services which are outside the control of an organization. The environment of a business organization is a fixed limitation/constraint to such an organization. So, it must be managed to the advantage of the organization. In other words, an organization must adapt or adjust to environmental demands if it intends to survive. The business environment contains those resources which an organization requires for survival. When an organization identifies those individuals who possess the resources they require for survival, the organization will negotiate with them to ensure a steady supply.

Furthermore, Kazmi(2002) in explaining the environment of business organization identified the external and internal environment. The external environment includes all the factors outside the organization which provide opportunities or pose threats to the organization. The internal environment refers to all the factors within an organization which impart, strengthen or cause weaknesses of a strategic nature. The environment in which an organization exists can, therefore be described in terms of the opportunities and threats operating in the external environment apart from the strengths and weaknesses existing in the internal environment

\section{Technological Environment}

Technology is one of the most pervasive factors in the environment of business organizations. Technology here refers to the sum total of knowledge, the ways thing are done. This includes inventions, techniques and vast store of organized knowledge about everything. Koontz, Odonnel and Weirich (1980) state that the main influence of technology on ways of doing things on how we design, produce, distribute and sell goods and services. Technological factors in the environment include advances in basic science such as physics as well as materials. The level of technology in society and in a particular organization determines to a large extent what products and services will be produced, what equipment will be used and how operations will be managed.

The technological environment can be regarded as the state of the use of scientific principles and mechanical arts to different tasks in the society. In the Nigerian context, the local technology is applied by those who engage in peasant farming, small scale businesses and even in the mining, quarrying and construction business. On the other hand, more advanced technology is engaged 
in the steel industry, the breweries, textile, banks and hospitals. Nigeria, Ghana, Liberia are not self sufficient in their technological input as they rely heavily on modern technologies from America, Japan, India, Korea, Europe. However, their dependence on foreign technologies has to some extent, advanced the technological climate positively

\section{Advantages of Technology in the Workplace Improves communication:}

Many businesses are using various business communication technologies to change the way their employees interact and communicate while at work. Employees can use various communication tools to interact or exchange information at work. For example, employees from different departments in a company can use text messaging services or video conferencing tools like Skype to share and exchange information. Virtual communication tools like Skype can be used to share screens and this can help workers to share projects while in different departments, the same application can be used to support group decision making. Also communication technologies can be used in the customer service department to serve customers on time (Dauda, and Akingbade, 2011).

\section{Encourages Innovation and Creativity}

Workers can use different business technologies to create innovative business ideas which can be used in business growth and expansion. Many companies create technological challenges and reward employees who come up with creative ideas using technology. Employees can use internet technology to innovate ways of promoting a business online.

\section{Improves on Human Resource Management}

Technology in the workplace can change the way human resource managers do their job. It improves the process of screening, recruiting and hiring new employees. Many human resource managers are using internet to advertise job openings. Targeted candidates will be in position to apply for these positions online by submitting their resumes to the human resource manager. It saves time and it makes the human resource managers work easier. Technology can also be used to track performance and productivity of each employee at work. Once employees are aware that they are being monitored, their productivity will increase (www.auctionexport.com).

\section{Saves Time}

Technology can be used to automate various tasks at work, this automation guarantees efficiency and will also increase on production at work. The use of computers to accomplish specific tasks at work creates room of making corrections on instant and it also reduces on human errors. Using databases to capture and store information can facilitate quick decision making at work. Employees can easily access business information via one single database; this information can be edited and saved for later use. Use of internal networks at the workplace can help in sharing of gadgets like printers and scanners, so employees do not have to move to different departments to share technological tools(Dauda, and Akingbade, 2011). 


\section{Disadvantages of Technology in the Workplace Causes Distraction at Work}

These are many ways technology can distract employees at work. The use of social networks at work can cause so much distraction and it affects the productivity of employees. Some companies have decided to block access to specific websites like Facebook, Twitter and Youtube, because of the unlimited distraction they cause. Other business technologies which cause distraction at work include smartphones, computers and virtual meeting applications like Skype.

High Maintenance costs: It is expensive to buy technology, but it is also costly to maintain it. Many small businesses can not afford the cost of hiring a full-time technical person, so they resort to monthly tech contractors who charge them for work done. If business technology tools like computers are not well maintained, their performance will decrease and the process of buying new computers or any other business technology can be more expensive(http://www.useoftechnology.com)

Makes employees lazy: Since most tasks are automated by technology, many employees become lazy at work, technology kills their creativity and skills. Simple tasks like calculating sales and tracking inventory are being done with computers, so you will find that employees do not put their brains to work, they cannot solvebusiness problems because a computer or software will do it with no challenge.

Affects Workplace Relationships: Employees communicate via cell phones, text messages, email or virtual video conferencing tools. This type of communication technology eliminates face-toface communication. Interpersonal communications are important in building workplace relationships because employees will get a chance to know each other in person, sometimes they can even share non-work related information, this type of interaction is killed by communication technology tools. Employees become more reserved and self-centered; they get buried into their work which can be of great harm to a business(Dauda, andAkingbade, 2011).

\section{Technological Environment and Competitive Strategies}

Strategic managers and theoreticians have long since recognized the importance of technology as a strategic dimension. Since the early 1980's there has been an understanding that technology is astrategic asset and needs to be managed accordingly (Arora, 1997; Hill, 1997; Frohman, 1980). The technological strategy-environment link is becoming more critical as boundaries between industries become blurred as a result of technological change (Kirschenbaum, 1990). Consequently, in the formulation of industry and business trends, managers must characterize technical trends. A good example of this is the rapid changes in the photography industry as computer technology crosses once formidable industry boundaries.

Technology is commonly defined as the process of converting input into output, through the use of knowledge, tools, techniques, and actions (Rousseau, 1979). This definition goes beyond the"production function" concept by introducing the technology environment interaction in an opensystems perspective. The open systems perspective treats technology as an inputconversion-output mechanism and thereby recognizes the qualitatively different types of 
activities that make up different competitive strategies (Jennings \& Lumpkin, 1992). The technological decision to license products or processes, is contingent upon the competitive strategy and managerial perceptions of the technological environment.

No single technological decision is optimum in every situation, therefore a contingency approach is appropriate. A contingency approach to strategy has been most clearly depicted in the environment strategy-structure paradigm (Chandler,1962). Murray (1988) shows the bilateral nature of a firm's relationship with its environment and the strategic implications of these external factors. He suggests that Porter's generic strategy concept can be clarified by linking each strategy to a set of environmental preconditions. Other research (Dvir, Segev, \& Shenhar, 1993; Brockhoff \& Pearson, 1992; Hambrick, 1983) has shown the intricate possibilities that can exist between Porter's generic strategies andMurray's environmental link.

While taking a similar approach, we are not concerned with deriving a typology of generic strategies between successful and unsuccessful firms. We are concerned with exploring the technological responsive., product/process licensing, of BUs in different strategic positions under different sets of technological preconditions. We assume that a BU operates in a technological environment based on managers' perceptions of technological conditions which are described as "stable" or "turbulent". Our research seeks to ascertain any commonalties in managers' response to licensing activity, when positioned competitively in their technological environments.

\section{Proxies of the Independent and Dependent Variables Perceived Usefulness}

Perceived usefulness is "the degree to which a person believes that using a particular system would enhance his or her job performance"(Davis, 1989). Perceived usefulness explains the user's recognition that the interactive mobile map innovation will enhance their task performance in conveniently finding locations (Davis, 1989). The user has a view of how valuable the innovation is in performing his or her tasks and how useful the mobile map is in reducing the time to get locations of where they are going to or where they are or getting the distance from a location to another location.

\section{Perceived Ease of Use of Technology}

Davis (1989) describes perceived ease of use as "the degree to which a person believes that using a particular system would be minimized. That is, utilizing a specific technology (like mobile map) would be free of physical and mental exertion. The user may accept that a given innovation (such as mobile map) is helpful, but while using the mobile, the user may find out that the innovation may be difficult to use. For instance, the object on mobile screen may be difficult to see. Ease of use is the user's impression of the measure of requirement needed to use a technology or the degree to which a user accepts that utilizing a specific innovation will be effortless and smooth.

\section{Innovation}

Innovation can be defined as the application of new ideas to the products, processes, or other aspects of the activities of a firm that lead to increased "value." This "value" is defined in a 
broad way to include higher value added for the firm and also benefits to consumers or other firms.

Two important definitions are:

\section{i. Product innovation}

The introduction of a new product, or a significant qualitative change in an existing product.

\section{ii. Process innovation}

The introduction of a new process for making or delivering goods and services.

\section{Technological Facilities}

These are tools, equipment and gadgets used for the systematic application of knowledge to enhance classroom teaching and learning. They include - computers, POS, ATM. Videos, overhead projectors, power point projectors, interactive televisions, interactive videos, software packages, flipcharts, interactive television, radios, network hardware, cellular phone, satellite system, photocopier, audio, photograph, digital camera, internet and other communication devices used in transmitting, processing, receiving, storing and retrieving information.

\section{Customer Satisfaction}

Customer satisfaction is defined as an overall evaluation based on the total purchase and consumption experience with the good or service over time (Fornell, Johnson, Anderson, Cha \& Bryant, 1996). With marketing, customer satisfaction also comes along with expectation that the needs of customer on goods and services are being facilitated by the companies. Actionable information on how to make customers further satisfied is therefore, a crucial outcome (Oliver, 1999).

\section{Employee Performance}

Performance is a multicomponent concept and on the fundamental level one can distinguish the process aspect of performance, that is, behavioral engagements from an expected outcome (Borman, \& Motowidlo, 1993; Campbell et al., 1993; Roe, 1999). The behavior over here denotes the action people exhibit to accomplish a work, whereas the outcome aspect states about the consequence of individual's job behavior (Campbell, 1990).

According to Nmadu (2013), employee performance is a degree of accomplishment of task(s) that make up an employee's job. This definition was in line with the definition given by business dictionary (2010), that employee performance is the accomplishment of a given task measured against pre-set standards of accuracy, completeness, cost and speed. Managers at workplace must ensure that employee activities and output contribute to the organization goals. This process requires knowledge of what activities and outputs are designed, observing whether they occur and providing feedback to help improve employee morale and to meet expectation (Nmadu, 2013). However, employee performance is associated with productivity which translates to quantity of output, quality of output, timeliness of output, presence or attendance on the job, morale at work, efficiency of the work completed and effectiveness of work completed (Mathis, Fredrick and Kenneth, 2009). 


\section{Theoretical Review}

\section{Technology Acceptance Model}

Technology Acceptance Model (TAM) was introduced by Davis (1986) as quoted in Davis, F. D., Bagozzi, \& Warshaw (1989). Technology acceptance model is an adaptation of Theory of Reasoned Action (TRA), developed to specifically deal with modeling user acceptance of information systems. As compared to TRA, Technology Acceptance Model is significantly less general. The model was developed to particularly explain the computer usage behavior. But since, TAM includes findings collected from over a decade of Information System (IS) research; it is particularly well-suited for modeling computer acceptance.

The Technology Acceptance Model (TAM) defines the casual relationship between perceived usefulness, ease of use, system design features, attitude towards using and actual usage behavior. In general, an informative representation of the mechanisms by which design choices influence user acceptance is provided by TAM. Hence, Technology acceptance model is useful in applied contexts for forecasting and evaluating user acceptance of information technology (Davis, 1993). According to Technology Acceptance Model (TAM), perceived usefulness (PU) and perceived ease of use (PEOU) are two key beliefs that are mainly relevant for computer acceptance behavior. Theory of Reasoned Action (TRA) is used by TAM as a theoretical basis to specify causal association between these two key beliefs i.e. PU and PEOUinfluences perceived usefulness (PU). PU also has a direct impact on behavioral intention (BI). Behavioral intention to use leads to actual system use.

The two key variables of technology are perceived usefulness and perceived ease of use. Perceived usefulness (PU) is defined from the prospective user's point of view. Will the application improve his or her job performance in the organization? Perceived ease of use (PEOU) is a variable that describes the perception of the user that the system will be easy to use.

\section{Empirical Review}

Muhammad and Nadeem (2014) conducted a study on the impact of technological advancement on employee performance in Nigeria banking sector. The purpose of this study was to check the impact of technological advancement on employee performance in banking sector. Methodology: This paper was completed with the help of extensive literature on technological advancement and employee performance

available on the databases and websites. Primary data was used in this paper to check the impact of technological advancement on employee performance. SPSS 16 software package was used to analyze the employee responses and statistical technique Regression analysis was used to check the impact of technological advancement on employee performance. The findings indicate that technological advancement has significant impact on motivation and training of employees. Motivation has significant impact on employee performance but training has no significant impact on employee performance.

Yunus and Waidi (2011) carried out a study on technological change and employee Performance in Selected Manufacturing firms in Lagos State of Nigeria. This study examined how employee relation could be employed for technological change management. It also sought to determine 
effective method of using technological innovation for improved performance in the Nigerian manufacturing industry. Two hypotheses were formulated to determine the relationship between technological change and employee skill; and between technological change and employee performance. Questions based on the hypotheses were formulated and 1256 copies of a questionnaire were distributed to selected 30 manufacturing industry in beverages, textile, steel, cement and chemical firms in Nigeria. Findings reveal that employee relation does not have a significant relationship with technological change. The paper recommended that employee relations should be considered in the management of technological change for profitability, competitiveness and survival of the Nigerian Manufacturing industry.

Luqman, Abimbola and James (2013) conducted a study on the effects of Business Environments on corporate strategies and performance of construction organizations in Kenya. The study examined the moderating effects of business environment in the relationship between strategies used by construction organisations and examined how these can be used in attaining competitive advantage, and improved corporate performance. The grounds for the examination stems from arguments by researchers that efficient and effective business strategy is an essential tool employed by organisations to direct their business endeavours to the ever changing business environment and record continuous improved performance. The study involved a meta-study of extant literature on construction business environments and business strategies in-use. From this approach, a conceptual framework was proposed for relating business environment and corporate strategies used by construction organisations to their corporate performance that could serve as the basis for further studies in construction organisation strategic planning. Preliminary results of a pilot survey to examine the moderating effects of environmental dimensions on strategies and organisational performance are provided in support of the concept developed. The results revealed that organisations adopt differentiation strategies to ensure survival in a complex business environment. It thus concluded that dimensions of business environment have moderating effects on organisational strategies and performance

Balogun (2016) studied the effects of Information Technology on Organisational Performance in Nigerian Banking Industriesexamined customer's and employee's responses to technology innovation, and their effects on the performance of the Nigerian banks. Fifteen (20) major banks were selected for the research. Two null hypotheses based on sets of questionnaires distributed to selected banks' employees and customers were formulated to test whether there is no significant relationship between technology innovation and customer's satisfaction; and between technological innovation and Nigerian banks employee's performance. Four hundred and fifty (450) questionnaires were distributed to customers to test the first hypothesis out of which 400 were collected which is $88.88 \%$ of the distributed questionnaires, Chi square was used to test the hypothesis. Findings revealed that technological innovation influenced banks employee's performance, customer's satisfaction and improvement in banks profitability. The study recommends effective management of technological innovation for improved employees performance, customer's satisfaction, sustainable profit, increased return on investment, returns on equity, and to promote competitiveness in the Nigerian banking industry. 
Ana and Olivier (2017) carried out the study on the technological environment and Technology Entrepreneurship: A Cross- Country Analysis This study investigated the relationship between the technological environment (measured by the amount of investment in R\&D, and access to Information and Communication Technology infrastructure) and technology entrepreneurship, in 54 countries during the years 2005 to 2010. Using data from the Global Entrepreneurship Monitor, and the World Bank Development Indicators, we identify a significant, robust invertedU-shaped relationship between R\&D investment at country level and the likelihood of technology entrepreneurship. We also find evidence of a positive relationship between access to Information and Communication Technology infrastructures and the likelihood of technology entrepreneurship.

Muhammad and Nadeem (2014) studied the impact of technological advancement on employee performance in banking sector in South Africa. Methodology: This paper was completed with the help of extensive literature on technological advancement and employee performance available on the databases and websites. Primary data has been used in this paper to check the impact of technological advancement on employee performance. SPSS 16 software package is used to analyze the employee responses and statistical technique Regression analysis is used to check the impact of technological advancement on employee performance. Findings: Total of 140 questionnaires has been distributed among different banks and out of which 100 were get completed and returned. After analyzing the data very efficiently, it was discovered that technological advancement has significant impact on motivation and training of employees. Motivation has significant impact on employee performance but training has no significant impact on employee performance. Moreover as the concerned for technological advancement and employee performance, there is significant relationship among them.

Michael, Christopher and Dorothy (2017) carried astudy on influence of technological environment on performance of gated community housing projects in Nairobi County, Kenya. The study population comprised of all active gated community housing projects initiated in 2009 - 2014. A total of 572 respondents were drawn from 143 sampled gated community housing projects from the seventeen sub-counties of Nairobi County (four members were drawn from each sampled gated community project - client, consultant, contractor, and the gated community facility manager) using census, stratified, simple random, and purposive sampling techniques. A standardized open ended interview guide and a questionnaire with both open and closed-ended items with Likert-type interval scale anchored on a five point scale were used to collect data. Descriptive statistics show that respondents agreed that to a very great extent their projects used locally made plant and equipment $(M=4.80, S D=0.40)$, to a great extent skills were available for operation of the plant and equipment $(M=4.04, S D=0.47)$, to a great extent team members with necessary skills to operate and use the plant equipment were available( $M=4.0$, $\mathrm{SD}=0.43$ ), to a very great extent use of information and communication technology (ICT) was satisfactory $(M=4.49, S D=0.71)$, to a very great extent computer aided drafting (CAD) was used $(M=4.62, S D=0.71)$, to a very great extend $3 D$ visual illustrations - Building Information Modelling, was used ( $M=4.65, S D=0.48)$, and

to a very extent electronic mails and communication was used $(M=4.86, S D=0.34$. Results from inferential statistics show that $r$ is equal to 0.559 , indicating that technological environment has 
a moderately strong influence on performance in gated community housing projects. The value of $r$ squared is 0.312 , indicating that technological environment explains $31.2 \%$ of the variation in the performance in gated community housing projects in Nairobi County, Kenya. The $\beta$ coefficient is 0.327 , indicating that technology environment had statistically significant influence on the performance of gated community housing projects $(\beta=0.327, t=4.758, p=0.000<0.05)$. Considering the $p$ value, it can be noted that the $p$ value for technological environment $(p=0.000)$ is statistically significant. The $\beta$ value imply that one unit change in performance in gated community housing project is associated with $32.7 \%$ changes in technological environment.

\section{Methodology}

Methodology encompasses the overall research plan and design that guided the process of data collection and the approaches used to collate the data. Specifically, the chapter contains research design, sources of data, description of research instrument, population of the study, Sample size determination, sampling techniques, validity and reliability of the instrument and the statistical tools for data analysis.

\section{Research Design}

Agbaeze (2004) describes research design as a map or plan of action showing what and how the researcher will carry out the step-by-step procedure for accomplishing the research task. For the purpose of this study, survey research design was adopted. This design helped the researcher to collect, record data and interpret data for effective decision making.

\section{Sources of Data}

The data for this study were obtained specifically from two sources namely: primary and secondary sources.

\section{(a) Primary Source of Data}

Primary source of data were original data collected basically for the purpose of the study. In collecting primary data for the study, two devices were employed: observation and questionnaire (b) Secondary Source of Data

The secondary source involved the use of existing but related literature, which was produced by earlier researchers for the purpose of the study. Secondary data for this study were obtained from journals, magazines, text-books and internet.

\section{Population of the Study}

The target population of the study includes the senior and junior Staff of the following commercial banks, which include First bank, Union bank, Diamond bank, Zenith bank and GTB plc. Enugu State have 17 LGAs and 260 wards. The state has urban and rural LGs and I chose the banks that have strong urban and rural presence in the state. The population of the respondents were based on the regional headquarters of the banks in Enugu urban. 
INTERNATIONAL JOURNAL OF ACADEMIC RESEARCH IN BUSINESS AND SOCIAL SCIENCES

Vol. 10, No. 6, June, 2020, E-ISSN: 2222-6990 @ 2020 HRMARS

Table 3.1 Population Distribution

\begin{tabular}{|l|c|}
\hline Name of banks & Population \\
\hline First Bank & 82 \\
\hline Union Bank & 72 \\
\hline Diamond Bank & 67 \\
\hline Zenith Bank & 64 \\
\hline GTB Plc. & 59 \\
\hline TOTAL & 344 \\
\hline
\end{tabular}

Source: Human Resource Department of Money Deposit Banks in the regional headquarters of the banks in Enugu urban

\section{Determination of Sample Size}

Sampling is the act of selecting and observing only a specified subset of the population unit (Ugwu: 2003),based on the above population. The formula adopted in determining the sample size for this study was that pro-pounded by Taro Yamani (1964) formula for sample size determination was adopted. The formula applied is thus:

$\mathrm{N}=\frac{\mathrm{n}}{1+\mathrm{N}(\mathrm{e})^{2}}$

Where

$\mathrm{n} \quad=\quad$ the sample size

$\mathrm{N}=$ the finite population

e $\quad=\quad$ level of significance

$1=$ a constant

Applying the formula, the sample size was calculated at 0.05 level of significance as follows.

$\mathrm{N}=\frac{344}{1+344(0.05)^{2}} \quad 1.86 \frac{344}{=185}$

A stratified sampling method was adopted so as to give a fair representation to the designated organizations. The Bowley's proportional allocation formula is given as:

$\mathrm{n}_{\mathrm{h}}=\mathrm{n} \mathrm{N}$

$\mathrm{N}$

Where:

$\mathrm{n}_{\mathrm{h}}=$ Number of units allocated to each firm/staff category.

$\mathrm{N}_{\mathrm{h}}=$ Number of employees in each firm/staff stratum in the population

$\mathrm{n}=$ Total sample size

$\mathrm{N}=$ The total population size under study
1. First bank Plc
$\underline{82 \times 185}=44$
344

2. Union bank Plc

$\underline{72 \times 185}=39$

3. Diamond bankPlc

$\underline{67 \times 185}=36$ 
4. Zenith bankPIc

$\underline{64 \times 185}=34$

5. GTB. Plc

$\underline{59 \times 185}=32$

Table 3.2 Allocation of Sample Size

\begin{tabular}{|l|c|c|}
\hline Name of Firm & Population & Sample \\
\hline First bank & 82 & 44 \\
\hline Union bank & 72 & 39 \\
\hline Diamond bank & 67 & 36 \\
\hline Zenith bank & 64 & 34 \\
\hline GTB plc. & 59 & 32 \\
\hline TOTAL & 344 & 185 \\
\hline
\end{tabular}

Source: Field Survey,2017

\section{Description of Research Instruments}

The instruments for data collection used in this research were a structured questionnaire, and observation. The questionnaire has two parts. All the questions in part A provides general information about the respondents while the remaining questions in part $B$ address the research questions. Five-point Likert scale format was used to design the questionnaire. There were 12 questions in the questionnaire.

\section{Validity of the Research Instrument}

Onwumere (2005) defined the validity of an instrument as the extent to which it performs on application the function for which it is designed .To make sure that the research instrument applied in this work is valid., a proper structuring of the questionnaire and a conduct of a pretest of every question contained in the questionnaire were carried out to ensure that they are valid. This was done by giving the questionnaire to management experts who modified the questionnaire and made the necessary corrections to ensure that it measure what it ought to measure. Also design of the questionnaire was made easy for the respondents to tick their preferred choices from the options provided as it has been established that the longer the length of questionnaire, the lower the response rate (Lavine, 1987).

\section{Reliability of the Research Instrument}

To ascertain that the instrument is reliable, a test-re-test method was adopted in which 15 copies of the questionnaire were distributed to the firms studied; three (3) copies to each firm. These were collected afterwards and re-distributed for the second time within period of two weeks. The outcome of the test-re-test was determined using spearman rank order correlation coefficient and the result gave a reliability coefficient of $r=0.62$. 
INTERNATIONAL JOURNAL OF ACADEMIC RESEARCH IN BUSINESS AND SOCIAL SCIENCES Vol. 10, No. 6, June, 2020, E-ISSN: $2222-6990 @ 2020$ HRMARS

\begin{tabular}{|l|l|l|l|l|l|}
\hline & Questionnaire item & Rank $^{\mathbf{1}}$ & Rank $^{2}$ & $\mathbf{d}$ & $\mathbf{d}^{\mathbf{2}}$ \\
\hline 1 & & 4 & 2 & 2 & 4 \\
\hline 2 & & 6 & 4 & 2 & 4 \\
\hline 3 & & 5 & 2 & 3 & 9 \\
\hline 4 & & 3 & 1 & 2 & 4 \\
\hline 5 & & 7 & 4 & 3 & 9 \\
\hline 6 & & 5 & 3 & 2 & 4 \\
\hline 7 & & 4 & 2 & 2 & 4 \\
\hline 8 & & 5 & 2 & 3 & 9 \\
\hline 9 & & 7 & 5 & 2 & 4 \\
\hline 10 & & 6 & 3 & 2 & 4 \\
\hline & & & & $\sum \mathrm{d}^{2}$ & 55 \\
\hline & & & & $\mathrm{n}$ & 9 \\
\hline & & & & $\mathrm{n}^{3}$ & 729 \\
\cline { 4 - 6 } & & & & $\mathrm{n}^{3}-\mathrm{n}$ & 720 \\
\hline
\end{tabular}

$\begin{array}{rll}r & = & 1-6 \sum d^{2} \\ r & = & 1-\underline{6 \times 55} \\ & & 729-9 \\ r & = & 1-\underline{6 \times 97} \\ r & = & 1-\underline{275} \\ r & = & 720 \\ r & = & 0.62\end{array}$

Data Analysis Techniques

Data were presented in tables and percentages. For the test of the hypotheses, Pearson product moment correlation coefficient was used to test hypothesis 2 while simple linear regression analysis was used to test hypothesis 1 and 3 using SPSS. 
INTERNATIONAL JOURNAL OF ACADEMIC RESEARCH IN BUSINESS AND SOCIAL SCIENCES

Vol. 10, No. 6, June, 2020, E-ISSN: 2222-6990 @ 2020 HRMARS

Presentation Of Data, Analysis and Interpretation

Table 4.1 Distribution of Questionnaire

\begin{tabular}{|l|l|l|l|l|l|l|}
\hline Banks Customers & $\begin{array}{l}\text { Number } \\
\text { distribute } \\
\text { d }\end{array}$ & $\%$ & $\begin{array}{l}\text { Number } \\
\text { returned }\end{array}$ & $\%$ & No returned & $\%$ \\
\hline First Bank Plc, & 44 & 23.78 & 40 & 22 & 4 & 2 \\
\hline Union Bank Plc & 39 & 21.08 & 35 & 19 & 4 & 2 \\
\hline UBA & 36 & 19.46 & 34 & 18 & 2 & 1 \\
\hline Zenith Bank Plc & 34 & 18.38 & 30 & 16 & 4 & 2 \\
\hline Access Bank Plc & 32 & 17.30 & 25 & 14 & 7 & 4 \\
\hline Total & $\mathbf{1 8 5}$ & $\mathbf{1 0 0}$ & $\mathbf{1 6 4}$ & $\mathbf{8 9}$ & $\mathbf{2 1}$ & $\mathbf{1 1}$ \\
\hline
\end{tabular}

Source: Field Survey, 2018

Table 4.1 indicates that out of 185 (100\%) copies of questionnaire distributed, 164 (86\%) were returned while 21 (11\%) were not returned.

Table 4.2 :The extent at which perceived usefulness of technology influence innovation and creativity in deposit money bank of Enugu state

\begin{tabular}{|l|l|l|l|l|l|l|l|}
\hline & Options & SA & A & D & SD & UD & Total \\
\hline 1 & $\begin{array}{l}\text { My understanding about the } \\
\text { importance of technology had } \\
\text { made me to be creative in my } \\
\text { service delivery }\end{array}$ & 107 & 49 & 5 & 3 & - & 164 \\
\hline 2. & $\begin{array}{l}\text { New creativity and innovative } \\
\text { ideas in my bank are as a result of } \\
\text { usefulness of technology in my e } \\
\text { banks }\end{array}$ & 50 & 101 & 7 & 6 & - & 164 \\
\hline 3 & $\begin{array}{l}\text { We carry out our task effectively } \\
\text { when we understand the } \\
\text { usefulness of technology }\end{array}$ & 120 & 38 & 3 & 3 & - & 164 \\
\hline 4 & $\begin{array}{l}\text { My bank generates new ideas } \\
\text { and products through the use of } \\
\text { technology }\end{array}$ & 111 & 46 & 5 & 2 & - & 164 \\
\hline Total & $\mathbf{3 8 8}$ & $\mathbf{2 3 4}$ & $\mathbf{2 0}$ & $\mathbf{1 4}$ & - & $\mathbf{6 5 6}$ \\
\hline
\end{tabular}

\section{Source: Field Survey, 2018}

\section{Hypothesis one}

Ho: Perceived usefulness of technology to a large extent does not influences innovation/creativity in deposit money bank of Enugu State

$\mathrm{Hi}$ : Perceived usefulness of technology to a large extent influences innovation/creativity in deposit money bank of Enugu State 
INTERNATIONAL JOURNAL OF ACADEMIC RESEARCH IN BUSINESS AND SOCIAL SCIENCES

Vol. 10, No. 6, June, 2020, E-ISSN: 2222-6990 ๔ 2020 HRMARS

Table 4.2a Model Summary ${ }^{b}$

\begin{tabular}{|l|r|r|r|r|r|}
\hline $\begin{array}{l}\text { Mode } \\
\mathrm{I}\end{array}$ & $\mathrm{R}$ & $\mathrm{R}$ Square & $\begin{array}{c}\text { Adjusted R } \\
\text { Square }\end{array}$ & $\begin{array}{c}\text { Std. Error of } \\
\text { the Estimate }\end{array}$ & $\begin{array}{c}\text { Durbin- } \\
\text { Watson }\end{array}$ \\
\hline 1 & $.897^{\mathrm{a}}$ & .805 & .804 & .35531 & .276 \\
\hline
\end{tabular}

a. Predictors: (Constant), Perceived usefulness of technology

b. Dependent Variable: Innovation and creativity

Table 4.2b ANOVA ${ }^{a}$

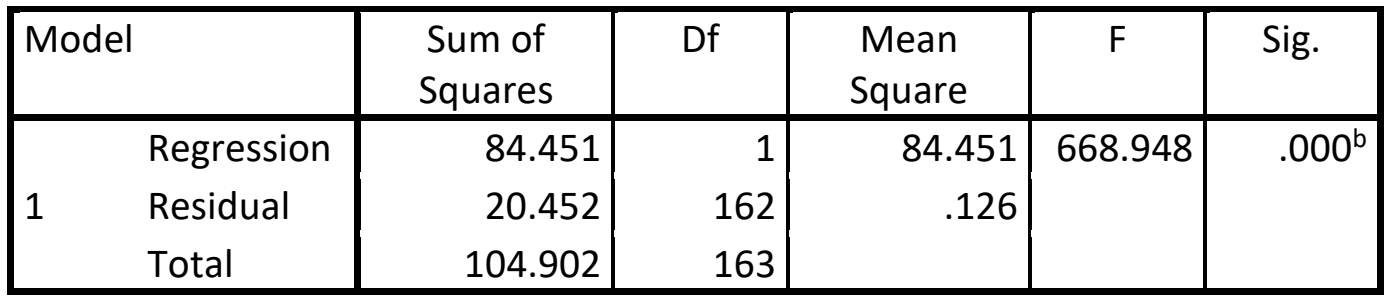

a. Dependent Variable: Innovation and creativity

b. Predictors: (Constant), Perceived usefulness of technology

Table 4.2c Coefficients ${ }^{\mathrm{a}}$

\begin{tabular}{|c|c|c|c|c|c|}
\hline \multirow[t]{2}{*}{ Model } & \multicolumn{2}{|c|}{$\begin{array}{c}\text { Unstandardized } \\
\text { Coefficients }\end{array}$} & $\begin{array}{c}\text { Standardized } \\
\text { Coefficients }\end{array}$ & \multirow[t]{2}{*}{$\mathrm{t}$} & \multirow[t]{2}{*}{ Sig. } \\
\hline & B & Std. Error & Beta & & \\
\hline (Constant) & 201 & .058 & & 3.448 & .001 \\
\hline $\begin{array}{l}\text { Perceived usefulness of } \\
\text { technology }\end{array}$ & .940 & .036 & .897 & 25.864 & .000 \\
\hline
\end{tabular}

a. Dependent Variable: Innovation and creativity

$\mathrm{R}=0.897$

$\mathrm{R}^{2} \quad=0.805$

$\mathrm{F} \quad=668.948$

$\mathrm{T}=3.448$

$\mathrm{DW}=0.276$

\section{Interpretation}

The regression sum of squares (84.451) is greater than the residual sum of squares (20.452), which indicates that more of the variation in the dependent variable is not explained by the model. The significance value of the F statistics $(0.000)$ is less than 0.05 , which means that the variation explained by the model is not due to chance.

$\mathrm{R}$, the correlation coefficient which has a value of 0.897 , indicates that there is a strong positive relationship between perceived usefulness new technology and innovation and creativity. $R$ square, the coefficient of determination, shows that $80.5 \%$ of the innovation and creativity in deposit money banks is explained by the model. 
With the linear regression model, the error of estimate is low, with a value of about .35531. The Durbin Watson statistics of 0.276 , which is not more than 2 , indicates there is no autocorrelation. The perceived usefulness of new technology coefficient of 0.843 indicates a positive significance between perceived usefulness of new technology and, innovation and creativity in deposit money banks, which is statistically significant (with $t=3.448$ ). Therefore, the null hypothesis is rejected and the alternative accordingly accepted. Thus perceived usefulness of technology to a large extent influences innovation/creativity in deposit money bank of Enugu State.

Table 4.3: The nature of the relationship between perceived ease of use and customer satisfaction in deposit money bank of Enugu State

\begin{tabular}{|l|l|l|l|l|l|l|l|}
\hline & Options & SA & A & D & SD & UD & Total \\
\hline 1 & $\begin{array}{l}\text { Ease of use of ATM in my bank } \\
\text { encourages customer satisfaction }\end{array}$ & 103 & 53 & 5 & 3 & - & 164 \\
\hline 2. & $\begin{array}{l}\text { My bank achieve customer satisfaction } \\
\text { through educating and encouraging } \\
\text { customers on easiest method of using } \\
\text { E-banking }\end{array}$ & 152 & 8 & 2 & 2 & - & 164 \\
\hline 3 & $\begin{array}{l}\text { Mybanks accuracy in the usage E- } \\
\text { banking promotes } \\
\text { satisfaction }\end{array}$ & 105 & 1 & 3 & - & 164 \\
\hline 4 & $\begin{array}{l}\text { There is a positive relationship between } \\
\text { perceived ease of use of technology and } \\
\text { customer service in deposit money }\end{array}$ & 121 & 38 & 4 & 1 & - & 164 \\
\hline & \begin{tabular}{l} 
Total \\
\hline
\end{tabular}
\end{tabular}

\section{Source: Field Survey, 2018}

\section{Hypothesis Two}

Ho: There is no positive relationship between perceived ease of use and customer satisfaction in deposit money banks of Enugu State

$\mathrm{Hi}$ : There is a positive relationship between perceived ease of use and customer satisfaction in deposit money banks of Enugu State

Table 4.3a Descriptive Statistics

\begin{tabular}{|l|r|r|r|}
\hline & Mean & \multicolumn{1}{|c|}{$\begin{array}{c}\text { Std. } \\
\text { Deviation }\end{array}$} & $\mathrm{N}$ \\
\hline $\begin{array}{l}\text { Perceived ease of } \\
\text { use } \\
\begin{array}{l}\text { Customer } \\
\text { satisfaction }\end{array}\end{array}$ & 1.5244 & .86833 & 164 \\
\hline
\end{tabular}

Table (4.3a) shows the descriptive statistics of the perceived easy to use via, customer satisfaction in deposit money bank with a mean response of 1.5244 and std. deviation of .86833 for perceived easy to use and a mean response of 1.5976 and std. deviation of .88421 for customer satisfaction in deposit money banks and number of respondents (164). By careful 
observation of standard deviation values, there is not much difference in terms of the standard deviation scores. This implies that there is about the same variability of data points between the dependent and independent variables.

Table 4.3b Correlations

\begin{tabular}{|ll|r|r|}
\hline & \multicolumn{1}{|c|}{$\begin{array}{c}\text { Perceived } \\
\text { easy to use }\end{array}$} & $\begin{array}{c}\text { Customer } \\
\text { satisfaction }\end{array}$ \\
\hline Perceived ease of & Pearson & 1 & $.740^{* *}$ \\
use & Correlation & & .000 \\
& Sig. (2-tailed) & 164 & 164 \\
Customer & Pearson & $.740^{* *}$ & 1 \\
satisfaction & Correlation & .000 & \\
& Sig. (2-tailed) & 164 & 164 \\
\hline
\end{tabular}

**. Correlation is significant at the 0.01 level (2-tailed).

Table (4.3b) is the Pearson correlation coefficient for perceived ease of use and customer satisfaction in deposit money banks. The correlation coefficient shows 0.740 . This value indicates that correlation is significant at 0.05 level (2tailed) and implies that there is a significant positive relationship between perceived ease of use and customer satisfaction of commercial banks ( $r=$ .740). The computed correlations coefficient is greater than the table value of $r=.195$ with162 degrees of freedom (df. $=n-2)$ at alpha level for a two-tailed test $(r=.740, p<.05)$. However, since the computed $r=.740$, is greater than the table value of .195 we reject the null hypothesis and conclude that there is a significant relationship between perceived ease of use and customer satisfaction in deposit money banks . $(r=.740, P<.05)$.

Table 4.4: Technological facilities for employee performance in deposit money bank of Enugu State

\begin{tabular}{|l|l|l|l|l|l|l|l|}
\hline & Options & SA & A & D & SD & UD & Total \\
\hline 1 & $\begin{array}{l}\text { My bank installed an ATM in order to } \\
\text { reduce work overload for bank staff }\end{array}$ & 120 & 40 & 1 & 3 & - & 164 \\
\hline 2. & $\begin{array}{l}\text { My bank introduce POS in order to } \\
\text { help bank staff not to be moved from } \\
\text { one market point to another for fund } \\
\text { collection }\end{array}$ & 126 & 31 & 4 & 3 & - & 164 \\
\hline 3 & $\begin{array}{l}\text { The staff in my bank can acquire new } \\
\text { skills through installation of new } \\
\text { technological devices }\end{array}$ & 107 & 52 & 2 & 3 & - & 164 \\
\hline 4 & $\begin{array}{l}\text { Technological facilities positively } \\
\text { influence employee performance in } \\
\text { my bank }\end{array}$ & 110 & 42 & 6 & 6 & - & 164 \\
\hline & Total & $\mathbf{4 6 3}$ & $\mathbf{1 6 5}$ & $\mathbf{1 3}$ & $\mathbf{1 5}$ & & $\mathbf{6 5 6}$ \\
\hline
\end{tabular}

Source: Field Survey, 2018 
INTERNATIONAL JOURNAL OF ACADEMIC RESEARCH IN BUSINESS AND SOCIAL SCIENCES

Vol. 10, No. 6, June, 2020, E-ISSN: 2222-6990 @ 2020 HRMARS

\section{Hypothesis Three}

Ho: Technological facilities do not significantly affect employee performance in deposit moneybank of Enugu State

Hi: Technological facilities significantly affect employee performance in deposit money bank of Enugu State

Table 4.4a Model Summary ${ }^{b}$

\begin{tabular}{|l|r|r|r|r|r|}
\hline $\begin{array}{l}\text { Mode } \\
\mathrm{I}\end{array}$ & $\mathrm{R}$ & $\mathrm{R}$ Square & $\begin{array}{c}\text { Adjusted R } \\
\text { Square }\end{array}$ & $\begin{array}{c}\text { Std. Error of } \\
\text { the Estimate }\end{array}$ & $\begin{array}{c}\text { Durbin- } \\
\text { Watson }\end{array}$ \\
\hline 1 & $.843^{\mathrm{a}}$ & .711 & .709 & .46964 & .239 \\
\hline
\end{tabular}

a. Predictors: (Constant), Technological facilities

b. Dependent Variable: Employee performance

Table 4.4b ANOVAa

\begin{tabular}{|c|c|c|c|c|c|c|}
\hline \multicolumn{2}{|c|}{ Model } & $\begin{array}{l}\text { Sum of } \\
\text { Squares }\end{array}$ & df & $\begin{array}{l}\text { Mean } \\
\text { Square }\end{array}$ & $F$ & Sig. \\
\hline \multirow{3}{*}{1} & Regression & 87.781 & 1 & 87.781 & 397.990 & $.000^{b}$ \\
\hline & Residual & 35.731 & 162 & .221 & & \\
\hline & Total & 123.512 & 163 & & & \\
\hline
\end{tabular}

a. Dependent Variable: Employee performance

b. Predictors: (Constant), Technological facilities

Table 4.4c Coefficients ${ }^{a}$

\begin{tabular}{|c|c|c|c|c|c|c|}
\hline \multirow{2}{*}{\multicolumn{2}{|c|}{ Model }} & \multicolumn{2}{|c|}{$\begin{array}{c}\text { Unstandardized } \\
\text { Coefficients }\end{array}$} & $\begin{array}{c}\text { Standardized } \\
\text { Coefficients }\end{array}$ & \multirow[t]{2}{*}{$\mathrm{T}$} & \multirow[t]{2}{*}{ Sig. } \\
\hline & & B & Std. Error & Beta & & \\
\hline \multirow[b]{2}{*}{1} & (Constant) & .303 & .078 & & 3.873 & .000 \\
\hline & $\begin{array}{l}\text { Technological } \\
\text { facilities }\end{array}$ & .891 & .045 & .843 & 19.950 & .000 \\
\hline
\end{tabular}

a. Dependent Variable: Employee performance

$$
\begin{array}{ll}
\mathrm{R} & =0.843 \\
\mathrm{R}^{2} & =0.711 \\
\mathrm{~F} & =397.990 \\
\mathrm{~T} & =3.873 \\
\mathrm{DW} & =0.239
\end{array}
$$

\section{Interpretation}

The regression sum of squares (87.781) is greater than the residual sum of squares (35.731), which indicates that more of the variation in the dependent variable is not explained by the model. The significance value of the F statistics (0.000) is less than 0.05 , which means that the variation explained by the model is not due to chance. 
$\mathrm{R}$, the correlation coefficient which has a value of 0.843 , indicates that there is positive relationship between technological facilities and employee performance. $\mathrm{R}$ square, the coefficient of determination, shows that $71.1 \%$ of the employee performance in deposit money banks is explained by the model.

With the linear regression model, the error of estimate is low, with a value of about .46964. The Durbin Watson statistics of 0.239 , which is not more than 2 , indicates there is no autocorrelation. The technological facilities coefficient of 0.843 indicates a positive significance between technological facilities and employee performance in deposit money banks, which is statistically significant (with $t=3.873$ ). Therefore, the null hypothesis should be rejected and the alternative hypothesis accordingly accepted. Thus technological facilities significantly positively affect employee performance in deposit money banks of Enugu State.

\section{Summary of Findings, Conclusion and Recommendation Summary of Findings}

The findings at the end of this study include the following

i. Perceived usefulness of technology to a large extent influences innovation/creativity in commercial bank of Enugu State $(r=0.897 ; F=668.948 ; t=3.448 ; p<0.05)$

ii. There is a strong positive relationship between perceived ease of use and customer satisfaction in commercial banks of Enugu State ( $r=.740, P<.05)$.

iii. Technological facilities significantly affect employee performance in commercial bank of Enugu State $(r=0.843 ; F=397.990 ; t=3.873 ; p<0.05)$

\section{Conclusion}

The study concluded that perceived usefulness of technology to a large extent influences innovation/creativity which in turn increases productivity and profitability. Again the study confirmed that there is a strong correlation between perceive ease of use of technology and customer satisfaction which indicate that when customers can easily use bank facilities the bank gains their loyalty and patronage. Furthermore, technological facilities significantly affect employee performance in deposit money banks of Enugu State.

\section{Recommendations}

Based on the findings of this study and the conclusion drawn there- from, the following recommendations are made:

i. Financial institutions need to encourage creativity and innovation through technology which will be of benefit to both employees and customers at large

ii. Financial institutions need to create a plat form where they will educate their customers on how to use most of E- banking facilities. That will go a long way to encourage customer satisfaction in most banks

iii. Financial institutions need to continuously upgrade their technological facilities, this will help in improving employee performance and at same time place them ahead of their competitors 
INTERNATIONAL JOURNAL OF ACADEMIC RESEARCH IN BUSINESS AND SOCIAL SCIENCES

Vol. 10, No. 6, June, 2020, E-ISSN: 2222-6990 @ 2020 HRMARS

\section{Suggestions for Further Studies}

Based on the findings, the following are highlighted for further study:

i. Influence of Technological facilities on employee performance in commercial bank of Enugu State.

ii. Effect of Perceived usefulness of technology on innovation/creativity in commercial bank of Enugu State.

\section{References}

Agbaeze, K. (2004) Fundamentals of research methods, Enugu, Optimal International Ltd.

Ana, L., and Olivier, J. (2017) carry out th study on the technological environment and Technology Entrepreneurship: A Cross- Country Analysis, Research Journal of Finance and Accounting 7(4)18

Arora, A. (1997). Patents, licensing, and market structure in the chemical industry, Research Policy, 26(4) 391-404.

Balogun, K. (2016) did a study on effects of Information Technology on Organisational Performance in Nigerian Banking Industries, Research Journal of Finance and Accounting $7(3) 11$

Bedřich, D., Veronika, F., \& Zdeněk, R. (2012).Technology, Environment, Economics, Management: Factors of Engineering Education in The Global World, 2 (7)6

Boddy, D., \& Buchanan, D. A. (1986).Managing New Technology. UK: Basil Blackwell

Brockhoff, K., \& Pearson, A. (1992). Technical and marketing aggressiveness and the effectiveness of research development, IEEE Transactions on Engineering Management, 39(4), 318324.

Campbell, J. P. (1990). Modeling the performance prediction problem in industrial and organizational psychology. In M.D. Dunnette \& L.M. Hough (Eds), Handbook of industrial and organizational psychology (pp. 687-732). Palo Alto, CA: Consulting Psychologists Press

Dauda, D. Y., \& Akingbade, W. A. (2011). Technological change and employee Performance in selected manufacturing industry in Lagos state of Nigeria. Australian Journal of Business and Management Research , 12(4)12

Davis, F. D. (1989)Perceived usefulness, perceived ease of use, and user acceptance of information technology, MIS Quarterly, 13, 319-340, (1989)

Davis, F. D. (1989). Perceived usefulness, perceive ease of use, and user acceptance of information technology. MIS Quarterly, 13(3), 319-340.

Davis, F. D., Bagozzi, R. P., \& Warshaw, P. R. (1989). User acceptance of computer technology: A comparison of two theoretical models. Management Science, 35(8), 982-1003.

Dugal, S., \& Roy, M. H. (1996). The allocation of R\&D funds between product development and process improvements: A follow-up study, Journal of Strategic Marketing, 4(2) 117-128.

Dvir, D., Segev, E., \& Shenhar, A. (1993). Technology's varying impact on the success of strategic business Units within the miles and snow typology, Strategic Management Journal, 14(3) 155-162.

Fornell, C., Johnson, D. M., Anderson, W. E., Cha, J., \& Bryant, E. B. (2017).The American customer satisfaction index: Nature, purpose, and findings, Journal of Marketing; 1996. Available:http://triton.nfh.uit.no/dok/fornell1996.pdf. Accessed 18 April 2017 
Frohman, A. L., (1980). Managing the companies technological assets, Research Management, September, 20-24.

Gemunden, H. G., Heydebreck, P., and Herden, R. (1992). Technological interweavement: A means of achieving innovation success, R\&D Management, 22(4), 359-376.

Goldhar, J. D., and Jelinek, M. (1983).Plan for economies of scope, Harvard Business Review, 61(2) 141-8.

Grindley, P. C., and Teece, D. J. (1997). Managing intellectual capital: Licensing and cross-licensing in semiconductors and electronics, California Management Review, 39(2) 34-42.

Hambrick, D. C. (1983). High profit strategies in mature capital goods industries: A contingency approach, Academy of Management Journal, 26,(7) 687-707.

Hampel, P. S., \& Martinsons, M. G. (2009).Developing international organizational change theory using cases from China. Human Relations, 62( 4), 459-99.

Hill, C. W. (1997). Establishing a standard: competitive strategy and technological Standards in winner-take-all Industries, Academy of Management Executive, 11(2) 7-26.

Jennings, D. F., \& Lumpkin, J. R. (1992). Insights between environmental scanning activities and porter's generic strategies: An empirical analysis, Journal of Management, 18(4), 791-803.

Madsen, S. R., Miller, D., \& John, C. R. (2005). Readiness for organizational change: do organizational commitment and social relationships in the workplace make a difference. Human Resource Development Quarterly, 1(2) 213-33.

Michael, C., Christopher, G., and Dorothy, N. (2017) Influence of technological environment on performance of gated community housing projects in Nairobi County, Kenya, European Scientific Journal Vol.13, No.11

Muhammad, I., Nadeem, M., \& Huzaifah, S. (2014) Impact of Technological Advancement on Employee Performance in Banking Sector, International Journal of Human Resource Studies, 4,(1)14

Muhammad, R., and Nadeem, M. (2014)Impact of technological advancement on employee performance in banking sector, International Journal of Human Resource Studies, 4 (4)1

Murray, A. I. (1988). A Contingency View of Porter's Generic Strategies, Academy of Management Review, 13(3), 390-400.

Nmadu, G. (2013), Employees performance and its effects on their job performancein workplace.Pil, T.D. \& Leana, B.T. (2000), Employee empowerment in a technology advancedwork Environment. Ind. Manage. Data Sys., 110(1): 24-42.

Onwumere, J. U. J. (2005): Business and Economic Research Methods, Enugu Vougasen Limited.

Oyewobi, L. O., Windapo, A., \& Rotimi, J. (2013). The effects of business environments on corporate strategies and performance of construction organisations In: Smith, S.D and Ahiaga-Dagbui, D.D (Eds) Procs 29th Annual ARCOM Conference, 2-4 September 2013, Reading, UK, Association of Researchers in Construction Management, 691-701.

Pagell, M., Handfield, R. D., \& Barber, A. E. (2000).Effects of operational employee skills on advanced manufacturing technology performance, Production and Operations Management, 9 (3) 222-38.

Parnell, J. A. (2013).Strategic management: Theory and practice. 4th ed, Sage Publications

Roe, R. A. (1999). Work performance: A multiple regulation perspective. In C.L. Cooper \& I.T. Robertson (Eds), International review of industrial and organizational psychology (pp. 231-335). Chichester: Wiley Publishers 
INTERNATIONAL JOURNAL OF ACADEMIC RESEARCH IN BUSINESS AND SOCIAL SCIENCES

Vol. 10, No. 6, June, 2020, E-ISSN: 2222-6990 ๔ 2020 HRMARS

Rousseau, D. M. (1979). Assessment of technology in organizations: Closed versus open system approaches, Academy of Management Review, 4(4), 531-542.

Yunus, A. D., \& Waidi, A. A. (2011)Technological change and employee performance in selected manufacturing industry in Lagos state of Nigeria. Australian Journal of Business and Management Research 1(5) 32-43. 